\title{
Pay as You Drink for Sustainability of Community Water Projects
}

\author{
Anne Wairimu Ndiritu (PhD) \\ University of Nairobi, \\ Open and Distance e-Learning Campus, Nairobi, Kenya \\ Solomon Muriungi Mburung'a (PhD) \\ Kenyatta University, Solomon Muriungi, Nairobi, Kenya \\ Caroline Njoki Ndiritu (MA) \\ University of Nairobi, \\ Open and Distance e-Learning Campus, Nairobi, Kenya
}

Doi: 10.19044/esj.2018.v14n11p137 URL:http://dx.doi.org/10.19044/esj.2018.v14n11p137

\begin{abstract}
The main objective of this study was to investigate how community water projects are influenced by water user fee payment by the stakeholders. This study was carried out in Kieni Constituency, Nyeri County in Kenya. The research was based on the models of sustainability and theories of capital structure. The study was carried out in all the 73 water projects in Kieni Constituency. The units of analysis were all the chairmen of these projects together with 381 beneficiaries of the water projects. Two district water officers and 9 local bank managers were also included in the study. Structured questionnaires, interview and observation schedules were used as research instruments. Pearson's Product Moment correlation was used in ascertaining the relationships between the study variables and $\mathrm{F}$ statistic was used in testing the hypothesis that: there is no significant relationship between the amount of water user fees and sustainability of community water projects. The analysis showed that there was a correlation coefficient $\mathrm{r}=0.356$ depicting a moderate positive correlation which was significant at 0.10 significant level. This indicated a significant moderate positive relationship between water user fee and sustainability of community water projects. It was therefore concluded that an increase in water user fee moderately improves sustainability of community water projects. From the study findings, it was recommended that there is need to establish a sufficient level of water user fee and also a proper management of the collected water user payments
\end{abstract}

Keywords: Water user fee, Sustainability, community projects 


\section{Introduction}

The importance of water cannot be overemphasized especially because of its necessity for survival. Lack of this important commodity has led to many deaths as well as underdevelopment of many countries. Studies show that lack of safe water directly contributes to the perpetuation of underdevelopment for many countries (UNDP2006). Research has also linked it to lower literacy levels and an oppression of women and children's rights (UNAIDS, WHO, 2007).The provision of quality water has therefore been a major concern of people all over the world. Kenya government like all the other countries has invested a lot of funds in the provision of quality water. A lot of funding has been provided by both the government and other donor agencies with the aim of improving livelihoods. However, the actual delivery of water supply and sanitation services do not match the concern leaving gaps in effectiveness and consumer satisfaction (Mwemba 2013). The water aid that has been provided by the developed countries has had limited success in providing sustainable water solutions. This study sought to determine if one of the reasons for lack of success of water sustainability is lack of water use payment by the stakeholders.

Access to safe water can be seen as one of the most basic human needs and rights. This is because water is very important for human health and wellbeing. This access to safe drinking water is so important that many international organizations use this as a measure for progress that can reduce the rate of poverty, diseases and even death (Smakthtin et al., 2004). It is unfortunate therefore that billions of people in many countries especially in developing countries still lack this important commodity(Ofwat, 2006). This problem is greatest in Africa which accounts for 19 out of the 25 Nations of the world without access to safe drinking water (Winpenny, 2001). Unsafe water, sanitation and hygiene (WASH are responsible for $4.2 \%$ of global burden of disease as measured in disability-adjusted life years (DALYs) making inadequate WASH the fourth largest global health problem (WHO, 2009).

Lack of safe drinking water or water scarcity is one of the world's leading global problems that affect more than 2 billion people. This translates to one in every six people lacking access to adequate drinking water (World Bank, 2011). According to WHO \& UNICEF (2006), 80\% of the population not accessing drinking water is found in three regions, that is, Eastern Asia, Southern Asia and sub-Saharan Africa,. Water accessibility is above $78 \%$ in all regions except sub-Saharan Africa. In sub Saharan Africa water accessibility stands at 50\%. WHO \& UNICEF (2013) estimated that, 300 million people lack safe drinking water in Africa. Kenya was identified as one of the top ten countries with the high population without access to drinking water. 
Kenya as a developing country has made some steps in provision of water to its citizens. Many water projects have been established by the government, community and individuals. Most of the government water projects have also had some support from the non-governmental organizations. Studies however show that most of these projects once established cease to operate a few years (Ministry of water and Irrigation, 2007) Sustainability of these water projects has been attributed to technical, institutional, financial social and environmental factors. Although many countries tried to achieve the millennium Development Goals: Goal 7, which was to Halve the proportion of population without sustainable access to safe drinking water and basic sanitation, Kenya was still unable to achieve this. (UN 2013). It is still upon Kenya to try to achieve the same goal under the $6^{\text {th }}$ global Sustainable Development Goals. Many non-governmental organizations and national governments have invested a lot of resources initiating water projects especially in rural areas which are managed by communities. Such water projects are the ones are in Kieni constituency (Scanlon, Cassar \& Nemes, 2004). Water projects are implemented to ease accessibility of the community members to clean water and hence improve their well-being (quality of life). Implementation of these projects is always successful but their sustainability poses a challenge. This necessitates studies to show how these projects can be sustained. This study was therefore guided by two objectives:

1. To establish the extent to which stakeholders paid for water as they used from water projects

2. To investigate how community water projects are influenced by water user fee payment by the stakeholders.

One hypothesis was developed to guide the study

$\mathrm{H}_{0}$ There is no significant relationship between water user fee and sustainability of community water projects.

\section{Statement of the problem}

Access to quality water and sanitation has been identified as one of the major foundations for achieving the Sustainable Development (UN). The world is able to better manage production of food and energy and contribute to decent work and economic growth if there is water sustainability.

Every country should play its part in ensuring the sustainable development goals are achieved. Kenya as one of the developing countries in its constitution 2010 clearly underlines the importance of provision of clean water to its citizen. Under article 43 (d) the constitution guarantees every Kenyan the right to have water that is clean, safe and affordable. Unfortunately it is reported that around 1.8 billion people globally use a source of drinking water that is unsafe. It is also reported that more than only $60 \%$ of people has 
access to this scarce resource. UN reports that the $40 \%$ for people without access to clean water is likely to rise. (UNICEF/WHO Water for life, 2005). The crisis is worse in developing countries, especially in Sub-Saharan Africa and South Asia.

Access to safe drinking water results in significant health, economic, and social gains since it contributes towards healthy communities. No economic activity that can take place without water. Further researches confirm that water is an essential natural resource, and indispensable for life. It is indeed a pre-requisite for growth and prosperity for mankind (Hurton et al 2007) other Scholars such as Getachew (2005) looks at the benefit of water not just from the political point of view but also from the economic point. From the economic benefits point of view, Getachew says that increasing the amount of water that is available to the point of use can help productive activities to take place. Davis and Gerry (1993) however reports a health dimension by reporting that access of safe and clean water can reduce the many infectious diseases which are relate to unsafe water especially in developing countries.

Access to safe water is pegged to functioning and sustainability of the water systems. The low levels of sustainability of water projects reduced the chances of achieving the Millennium Development Goals, which was to half the proportion of people globally without access to safe drinking water (UN, 1992). In Kenya, 41 per cent of Kenyans do not have access to adequate drinking water supply through point sources, piped systems, and rainwater harvesting systems (World Bank, 2011).

Access to water has been a challenge worldwide. According to a report by WHO/UNICEF 2017, the total number of people without access to safely managed drinking water services is 2.1 billion (UN 2017). Rural water supply is declining at an alarming rate not just in Kenya but in other parts of the world as indicated by statistics across the world (Clark 1988, McPherson 1994, Taylor \& Mudege, 1996). In Kieni Constituency, Nyeri County, Kenya, majority of the community water projects were not operating at full capacity, with between 60 percent and 65 percent of all boreholes in Kieni either do not function at all, or operate significantly below designed expectations (KFSSG, 2012).Some of the reasons given for this decline are lack of participation by rural communities who are the end users in planning, implementation and management of water supply facilities and weakness in the operation and management of water supply facilities (Churchill, 1987, Kimena 1998). The high number of water points falling out of use threatens sustainability of the rural water supply which will further impact on the achievement of sustainable development goals (Musonda 2004) 


\section{Literature review}

\section{Sustainability of Water Projects}

Different scholars define projects differently. Nokes and Sean (2007) for example describe a project as a set of coordinated activities with a specific start and finish time, pursuing a specific goal with constraints on time, scope and resources. Some projects require that their activities be sustained over time to ensure continued flow of outputs and hence achievement of the desired change which could be social, cultural or economic. Water projects like all other projects require sustainability over time for them to achieve their desired outcomes which could be social, cultural and economic ( Mwamburi 2014).

Although a lot of resources have been provided to improve the provision of water supply there are still problems associated with water projects' sustainability. In rural areas for example, there is marginal improvement recorded to match the amount of resources allocated for such development projects. Infrastructure in terms of pipes and channeling systems throughout the country has continued to deteriorate to such extent that a lot of it is lost through mismanagement before reaching the consumer. Studies on sustainability of rural water projects in different countries in Africa by Harvey \& Reed,2007, Adida ,2012, Beyene 2012, Musonda,2004, Abrams1998, and Shaw (2012), identified factors such as financial and economic issues; non supporting policy context; non-flexible institutional arrangements; community and social aspects; lack of spare parts supply; poor technology and the natural environmental issues; poor maintenance of projects; and lack of proper monitoring as the ones affecting rural water supply projects. Shaw (2012) for example indicated that, rural community water projects collect insufficient funds to cater for the required repairs and proper maintenance which led to lack of sustainability of rural water supply projects.

The importance of charging people for water use is necessary to ensure that people take responsibility in the proper use of this resource. Keissler (1997) asserts that charging for water use leads to sustainable water management. Water like all economic resources should be charged a market value. Hardin's (1968) confirms the same and explains that if people are allowed to use the environmental resources freely, they would seek maximum personal benefit through unsustainable use rather than use is sustainably for society as a whole.

Community Water supply project is a service, and just like any service project. It requires manpower, spare parts, repairs, energy and other inputs. According to Wyatt (1988), these requirements need funds. Hence, in order to implement and operate a sustainable water supply project, a cost recovery system must be in place. Establishment of water supply projects involve costs which must be incurred at the design stage, construction phase and in the operational phases of any water supply project. However, these costs depend 
on the type of management practices, technology used, and the geology. The costs can be classified into subunits as proposed by Whittington (2003) namely: Transportation costs for instance major pipelines and pumping facilities; production costs such as reservoir, tanks, pumps and treatment plants; distribution costs which include, metering and local reticulation; connection costs and administrative costs such as office expenditure, collection, billing and customer relation. Cost recovery systems were normally user fees of water tariffs, that is levying fees for water usage.

\section{Water User Fee}

Different researchers have found differing views on why water should be priced. For example, whittington (2003) is of the view that water is a social good and should therefore not be charged and therefore should be provided for free, however, Boland and Whittington (2003) are of the view that water is an economic good and therefore should be priced and not provided for free.

World Bank (1993 argues that the government can no longer afford to meet all the expenses and costs that are associated with the provision of water services. Nyoini (1999) agrees that users should be made to meet these expenses. Free water supply can however be associated with the wastage that goes with free things. Research has indicated that free provision for water is responsible for the poor financial performance and stability of water utilities in poor economies.

Many scholars have recommended payment for water as a necessity for sustainability of water projects. Their argument borders on the fact that it is not possible for the governments and donors to cover all the costs especially the recurrent costs of water service provision. Users of water must therefore share the burden. They also agree that the cost of maintaining access to clean water is not unreasonably high since the users have money to do other less important activities (Msukwa and Taylor 2011, Haysom, 2006). Payment of water charges also develops a sense of ownership and empowerment among the water users. There is evidence also that even the poorest and most underprivileged segments of the society are normally willing to pay for water supply so long as it is reliable (McPherson, 1994, Briscoe \&de Ferrenti, 1988). Other studies on water demand have found that poor people are more willing to pay for improved service than their rich neighbors (Briscoe \&de Ferrenti, 1988, Churchill, 1988). Churchill (1988) for example argues that most rural communities can afford to pay for the improved services, provided that appropriate technology is used. This he argued was because of the fact that the rural communities were already spending large amount of time and energy in water collection

According to Harvey and Reed (2004), sustainability of rural water project demands community financing and creation of efficient systems of 
operation, maintenance and repairs. According to Whittington et al (2008), a minority of rural communities in Ghana, Peru and Boliva were not collecting sufficient revenues to cater for operations and maintenance costs. In addition a significant minority of water projects were not collecting revenues at all. This led to breakdown and non-functionality of community water projects. This is one aspect this study aims at investigating, that is, the influence of water user fee on sustainability of community water projects in Kieni constituency.

A study by Gine and Perez-Foguet (2008) also noted the failure of community projects to generate sufficient revenues meant repairs were not done. They asserted that, communities should chose technologies that are cheaper and efficient and set tariffs that are commensurate with their economic status and hence affordable. However, Baumann (2006) stated that, the life expectancy of installed water supplies is greatly reduced if there is inability of communities to collect sufficient revenue for repairs. Therefore community water user fee need to be reasonable and take care of repairs and maintenance and other recurrent expenditure. Bannerjee and Morella (2011) suggested that, "an average of $1.9 \%$ of household income is spent by rural dwellers on water services in Africa, which is below the commonly cited 3\%-5\% affordability guideline". This therefore means most Africans do not value importance of water due to their low household expenditure on water. This therefore called for an investigation on water user the generated that is, their adequacy, and influence on sustainability of water projects.

Kleemeier (2000) stated that community members were reluctant to pay when everything appears to be working. Manyena et al (2008) found the majority of communities were willing to pay for water services, some did not have the ability to pay for the real cost of water. Whittington et al (2008) observe that, in rural communities cash flows are highly seasonal and have very little savings in rural communities. This, therefore, placed many community water projects in a situation they cannot generate enough of water user fee to cater for operation and maintenance of the established water systems.

Gine and Perez (2008) emphasized the need for realistic and transparent financing mechanisms in community projects. They noted that, contributions need to be well managed and invested in maintenance and repair for a project to be sustainable. Nedjoh et al (2003) argued that inadequate tariffs, lack of knowledge on maintenance costs, and high rates of defaulting by water beneficiaries in addition to poor financial management and ineffective collections influenced negatively the ability of community's projects to be financially sustainable. Wood (1994) on the other hand stated that, for some rural communities, projects with higher technology such as hand pumps represent an unaffordable technology. He suggested more austere rope 
and buckets as a lower-cost alternative. Such technology could reduce water tariff costs making water more affordable to Kieni constituents and reduce default payments of water tariffs and increase sustainability of community water projects.

Davis et al (1993) raised the question that whether in a community based $\mathrm{O} \& \mathrm{M}$ system, the poor rural communities can meet the full cost of operation and maintenance. WHO (1993) argued that beneficiaries can fully meet maintenance cost. Others argued that because of high poverty levels, meeting full costs of $\mathrm{O} \& \mathrm{M}$ by rural communities is difficult. According to Briscoe \& de Ferranti (1998), even in cases where the community members are willing to financially contribute to operation and maintenance of community water projects, they are hampered by lack of resources. McPherson (1994) argued that, there is growing evidence that even the most under privileged segments and poorest of society were willing to pay for water supply as long as it was reliable. UNCHR (1997) argued that, water demand in low and middle income generally, people are willing to pay a higher proportion of their income for improved services than their rich neighbors. In support of this view, Churchill (1998) also argued that some areas in various countries where poverty is extreme, the communities can afford to pay for improved water services, provided that appropriate technology is used. This could be attributed to the fact that people in rural areas are already spending high proportion of their time and energy in water collection. Kieni constituency is an arid area which receives inadequate rainfall yet majority practice agriculture as main source of livelihood. This situation requires investigation on whether the communities are willing to pay for water usage and its influence on sustainability of community water projects.

Water tariffs can be implemented for different reasons under different structures. In most cases water is charged so as to provide revenues to projects for the efficient delivery of water services. According to Brikke \& Rojas (2001), the operation and maintenance cost recovery was essential for the financial sustainability of water projects, proper and effective system maintenance, leading to provision of quality water services. According Magnusson (2004) water pricing promoted efficient and sustainable use of water. Whittington (2003) suggested that water pricing promoted fairness and equity in access to water and water use. He emphasized the need for transparency in pricing of water. Brown \& Holcombe (2004) stated that "a consumer, who consumes twice the quantity water, as another consumer, should pay a bill, that is, at least twice as large as that of the latter". However Ruijs et al (2008) had a different view that, fairness on pricing of water should be on the basis of affordability and socio-economic characteristics of the household. This is because water is essential for mare human survival. Therefore fairness in water user fee is essential to prevent negative 
consequences associated with the lack of access to safe and sufficient water supply and sustainability of community water projects.

Water tariffs can also be used to promote poverty alleviation. This is because the water tariffs will generate revenue for the extension of improved water supply services to the poor with relatively high economic and social returns (World Bank, 1993). The poor usually spend more of their financial resources on medical bills due to the consumption of poor quality water. Thompson et al (2001) had documented that improved water sources within households in East Africa and Manila, saves time for water collection and thereby to engage in productive activities which can generate revenue for their households and improve household incomes, and also reduce medical expenses due to improvement in health.

From the analysis of the 20 sub-Saharan African countries poverty reduction strategy papers (PRSPs), $85 \%$ of those countries had an emphasis on community management and financing of rural water supplies (Harvey, 2006). However, they did not adequately address the affordability of associated costs of water. This situation needs to change for improvement in the levels of sustainability and reduction of proportion of people without access to safe drinking water in rural Africa. The success of cost recovery system, as a determinant of sustainability, is affected by the extent to which water management committees are guided, supported and retrained, in relation to water user fee structures and financial management. If such external guidance is absent, then the success of cost recovery systems and efforts will diminish (Misgina, 2006).

\section{Negative impact of water fee charges on sustainability}

Although there is a lot of support for water user fee payment, there are scholars who are against the payment for water by users. They argue that user fees are too low to generate sufficient funds and are also not able to foster ownership(Whittington, Davis et al. 2008). When communities are told to cofinance this is likely to create feelings of injustice and resentment, rather that empowerment and ownership (Babajanian, 2011). A systematic review of willingness to pay for clean water in Bangladesh, Ghana, Kenya and Zambia showed that at even very low user charges put people off using clean water (Null, Kremer et al. 2012). The low willingness to pay is also as a result of people under estimating the benefit of water (Kremer and Miguel 2007, Dupas, 2009).

Sometimes the community is also unwilling to contribute the water charges. This unwillingness to pay for the services is influenced by a number of factors one of which is availability of alternative sources of water in the community for example a river though far( Roark et al. 1993, Briscoe \&de 
Ferrant, 1988). This study conceptualized the relationship between the independent and the dependent variables as follows:

Water user fee

Sustainability of water projects

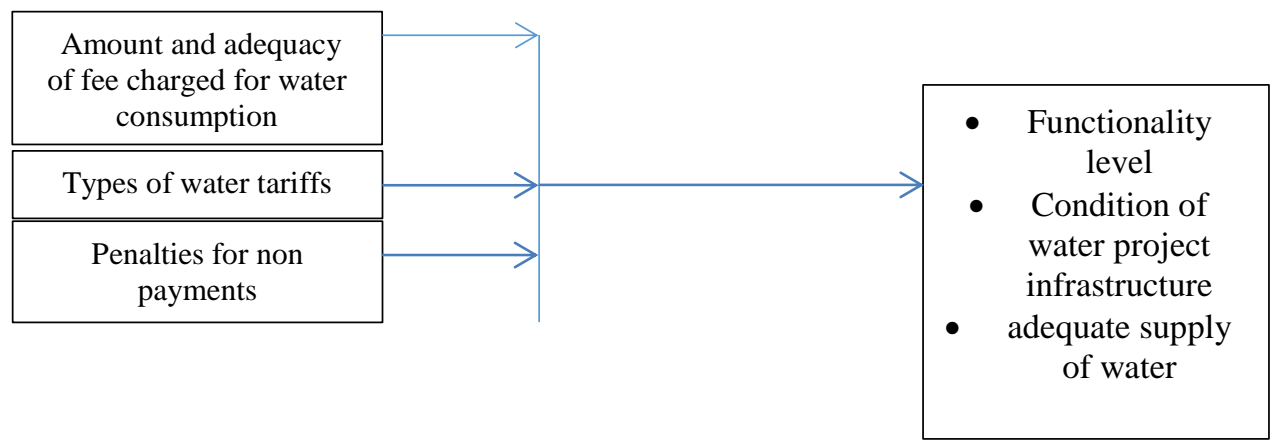

\section{Conceptual framework}

The study seeks to examine the relationship between water user fee as the independent variable and sustainability of community water projects.

\section{Research methodology}

Cross-sectional descriptive survey design was used in this study. This design was justified because the water projects were distributed across the geographical area of the study. The descriptive research design also combined both quantitative and qualitative approached which ensured the advantages of both (Scrimshaw, 1990, Rao \& Woolcock, 2003). The study adopted both probabilistic and non-probabilistic sampling designs. A census of all the 73 community water projects in Kieni constituency was studied. All the chairmen of the community water projects were included in the study. In addition, stratified random sampling was used to select 381 from a total of 51,304 beneficiaries. Two District water officers and 9 Nyeri bank branch managers were also studied. Data was collected using self-administered questionnaires, observation and interview schedules. This data was analyzed by use of descriptive statistics, and inferential statistics. Pearson Product Correlation Coefficient was used to ascertain the influence of water user fee on sustainability of community water projects. F-statistic was used for hypothesis testing. The study used $\alpha=0.10$ as the significant level. Multiple linear regression analysis was used for modeling of mathematical equation to depict the influence of the water user fee on sustainability of water projects. The following hypothesis was tested:

$\mathrm{H}_{0}$ There is no significant relationship between water user fee and sustainability of community water projects. 


\section{Research findings}

Water user fee was analyzed by assessing water connection fees, charges for water consumption and adequacy of water user fee. To do this, the respondents were asked to indicate the amount of money that they are charged for their water. Pearson Correlation Coefficient was used to find out the relationship between water user fee and sustainability of community water projects. Correlation coefficient $\mathrm{r}=.356^{*}$ indicated a moderate positive correlation between the variables. This correlation was also significant at 0.10 significant level. A conclusion was therefore made that an increase in water user fee moderately improve sustainability of water projects.

F statistic was also used to test this relationship. It was found to be equal to 16.781 , which was significant at $\mathrm{p}=0.00$ therefore the null hypothesis was rejected, meaning that there was a significant relationship between water user fee and sustainability of community water projects in Kieni Constituency, Nyeri county Kenya.

\section{Conclusions of the study}

The study concluded that, all community members pay fee to cater for water projects operations and maintenance except for dams and water pans whose water was free. All water beneficiaries pay same amount of water user fee irrespective of the amount used under the gravity water projects which leads to unsustainable water use and wastage of water.

There was a moderate positive relationship between water user fee and level of sustainability of community water projects. The correlation was also significant at 0.10 significant level. The null hypothesis four was rejected. Hence the study concluded that, there was significant relationship between adequacy water user fee and sustainability of community water projects in Kieni Constituency, Nyeri County.

\section{Recommendations}

Since there was significant relationship between water user fee and sustainability of community water projects, the study recommends that, an optimum level of water user fee be established and improvement of its collection and management to ensure proper utilization of the collected funds. Water user fee payment is also likely to ensure that the projects are well maintained since the related expenses will be taken care off. Stakeholders are also likely to use the water they fetch carefully since it will be costing them something.

\section{References:}

1. Abrams, L. (1998). Understanding sustainability of local water services. Retrieved from 
2. Adida, A. (2012). Financial Sustainability of Rural Water Supplies in Western Kenya.

3. Babajanian, B. V. (2011). Problematizing the community-contribution requirement in participatory projects: evidence from Kyrgyzstan. Development in practice, 21(3), 317-329.

4. Bannerjee E. \& Morella, H. (2011).Africa's Water and Sanitation Infrastructure: Access, Affordability, and Alternatives. Washington D C: World Bank.

5. Baumann, E. (2006). Do Operation and Maintenance Pay? Waterlines, 25.

6. Beyene, H. (2012). Factors affecting the Sustainability of Rural Water Supply Systems: The Case of MechaWoreda, Amhara Region, Ethiopia: A Project Paper Presented to the Faculty of the Elshorst Graduate School of Cornell University in Partial Fulfillment of the Requirements for the Degree of Master of Professional Studies.

7. Brikke, F. \& Rojas J. (2001).Key factors for sustainable cost recovery in the context of community managed water supply. Occasional paper series 32-E. Delft, The Netherlands, IRC International Water and Sanitation Centre. Rerieved from www irc.nl/content//download/2568/26552/file/op32e.pdf.

8. Briscoe J \& de Ferranti D. 1988. Water for rural communities: helping people to help themselves. Washington DC: The World Bank

9. Churchill A. 1987. Rural water supply: time to change. Discussion paper no. 18. Washington DC: World Bank.

10. Churchill, Anthony A. (1987).Rural Water Supply and Sanitation: Time for Change. Washington: The World Bank.

11. Clark, L. (1988). Field guide to water wells and boreholes. Open University Press.

12. Davis, J., Garvey, G., and Wood, M., (1993).Developing and Managing Community Water Supplies (Oxfarm Development Guideline Series: NO. 8) Oxfarm, UK

13. Department for International Development (DFID) (1998) "Guidance Manual on Water Supply and Sanitation Programmes" Department for International Development/Water and Environment: London.

14. Faculty of Civil Engineering Department of Water Management and Sanitary Engineering Section: Delft University of Technology.

15. Getachew, Z. (2005). Determinants of sustainable rural water supply system in ethiopia the case of two rural water supply systems: amuyee serra and habru seftu schemes.

16. Gine, A. \& Perez-Foguet, (2008).Sustainablity assessment of National Rural Water supply Program in Tanzania. Natural resources Forum Volume 32 pages 327-342. 
17. Hardin, G (1968) The Tragedy of the Commons' Science, 162, p12438

18. Harvey, P. \& Reed, R. (2007). Community-Managed Water Supplies in Africa: Sustainable or Dispensable? Community Development Journal 42(3), 365.

19. Haysom, A. (2006). A study of the factors affecting sustainability of rural water supplies in Tanzania, Msc Thesis, Silsoe: cranfield university.

Retrieved

from www.wateraid.Org/other/startdownload.asp.

20. http://www.africanwater.org/sustainability.htm

21. Kessler, P (1997) Economic Instruments in Water Management. In Kay, M, Franks, T, Smith, L (eds) (1997) Water: Economics, Management and Demand, E \& FN Spon, Suffolk, UK

22. Kleemeier, E. (2000). The Impact of Participation on Sustainability: An Analysis of the Malawi Rural Piped Scheme Programme. World Development Volume 28, No. 5 pages 929-944.

23. Kremer, M., \& Miguel, E. (2007). The illusion of sustainability. The Quarterly Journal of Economics, 122(3), 1007-1065.

24. Manyena, S.B., Mutale, S.B., \& Collins, A. (2008).Sustainability of rural water supply and disaster resilience in Zimbabwe. Water Policy. 10, 563-575.

25. McPherson, H.J.(1994). Operations and Maintenance of Water Supply and Sanitation Systems: Case Studies. Geneva; WHO.

26. Ministry of Water and Irrigation, (2007). Annual Water Sector Review 2007, 11-16 "Water sector financial turnout". Retrieved 1 March 2013.

27. Misgina, G. (2006).An assessment of challenges of sustainable rural water supply: The case of Oflaworeda in Tigray Region (Doctoral dissertation, School of Graduate Studies Regional and Local Development Study (Rlds). An Assessment of Challenges of Sustainable Rural Water Supply: The Case of OflaWoreda in Tigray Region A Thesis Presented to the School of Graduate Studies, Addis Ababa University).

28. Msukwa, C. A. P. S., \& Taylor, D. (2011). Why can't development be managed more like a funeral? Challenging participatory practices. Development in practice, 21(1), 59-72.

29. Mukherjee, N. \& Van Wijk C. (2003). "Sustainability Planning and Monitoring in Community Water Supply and Sanitation". Water and Sanitation program/IRC2003.

30. Musonde, K. (2004). Issues Regarding Sustainability of Rural Water Supply in Zambia. The University of South Africa, M.A in Social Science Dissertation. 
31. Nedjoh, J., Thogersen, J., \& Kjellerup, B. (2003). Challenges of O\&M in the sustainability of rural water facilities. In 29th WEDC International Conference: Towards the Millennium Development Goals.

32. Nkhuwa, D. C., Mweemba, C., \& Kabika, J. (2013). Country Water Resources Profile for Zambia. unpublished report, University of Zambia, http://nepadwatercoe. org/resources/nepad-watercoescountry-water-resource-profiles/ (accessed 30 January 2014).

33. Nokes, S., \& Kelly, S. (2007). The definitive guide to project management: the fast track to getting the job done on time and on budget. Pearson Education.

34. Null, C., Kremer, M., Miguel, E., Hombrados, J. G., Meeks, R., \& Zwane, A. P. (2012). Willingness to pay for cleaner water in less developed countries: systematic review of experimental evidence. The International Initiative for Impact Evaluation (3iE).

35. Nyoni, J. M. (1999). Water Pricing Issues In Developing Country: Case of Zimbabwe International Journal of Social Economicshttp://elibrary.ru/contents.asp?issueid=247136.

36. Rao, J.O. (2013). Effect of Funding Sources on Financial Sustainability of Water Sector Institutions in Kenya. University of Nairobi: URI: http://erepository.uonbi.ac.ke:8080/xmlui/handle/123456789/58807 .

37. Roark P, Hodgkin, J \& Wyalt A. 1993. Models of management systems for operation and maintenance of rural water supply and sanitation facilities

38. Ruijs, A., Zimmerman, A., \& Van Den /Berg, M., (2004). Demand and Distributional Effects of Water Pricing Policies. Ecological Economies. 66 (2-3); 506-516.

39. Scanlon, J., Cassar, A., \& Nemes, N. (2004). Water as a Human Right? IUCN Environmental Policy and Law Paper No. 51. International Union for Conservation of Nature and Natural Resources, UK.

40. Scrimshaw, S. C. (1990). Combining quantitative and qualitative methods in the study of intra-household resource allocation (pp. 8698). Tokyo, United Nations University Press.

41. Shaw, D. (2012). An Assessment of Rural Water Supply Sustainability in Monze District, Zambia. A dissertation submitted to the University of Bristol in accordance with the requirements of the degree, Master of Science by advanced study in Water \& Environmental management, in the Faculty of Engineering.

42. Smakhtin, V., Revenga, C., \& Döll, P. (2004). A pilot global assessment of environmental water requirements and scarcity. Water International, 29(3), 307-317. 
43. Taylor, P., \& Mudege, N. R. (1996). Sustainability: the challenge of rural water supply and sanitation in Zimbabwe. IWSD: Harare.

44. UNAIDS, W. (2007). 2007 AIDS epidemic update. PDF). December.

45. UNESCAP, A. UNDP. (2006). Millennium Development Goals: Progress in Asia and the Pacific.

46. UNHCR, (1997).Partnership in Water Sector for Cities in Africa. Report of Cape Town Consultants, Cape Town: UNHS/DWSF/UNDP

47. UNICEF (2017) Progress on drinking water, sanitation and hygiene: 2017 update and SDG baselines

48. Water, U. N. (2013). Water security and the global water agenda: a UN-water analytical brief. Hamilton, ON: UN University.

49. Whittington, D. (2003). Municipal water pricing and tariff design: a reform agenda for South Asia, Water Policy, 5, 61-76.

50. Whittington, D., Davis, J., Prokopy L., Komives, K., Thorsten, R., Lukacs, H,,Bakalian, A., \&Wakeman, W., (2008). How well is the demand-driven, community management model for rural water supply systems doing? Evidence from Boliva, Peru, and Ghana. The University of Manchester Brooks World Poverty Institute, BWPI Working Paper 22.

51. Who, U., \& Unicef. (2009). TOWARDS UNIVERSAL ACCESS: Scaling up priority HIV/AIDS interventions in the health sector.

52. Wood, M. (1994). Community Management of rural water supplies. Waterlines, 12(3), 6-9.

53. World Bank (1993). “Village Infrastructure Project for Java”.Staff Appraisal Report.Country Department III.East Asia and Pacific Region. The World Bank. Washington, D.C. April 26.

54. World Bank (2011).Financing Small Piped Water Systems in Rural and Peri-urban Kenya. World Bank ": New York.

55. Wyatt, J. M. (1988). Biotechnological treatment of industrial waste water. Microbiological sciences, 5(6), 186-190. 